\title{
IDENTIFIKASI FAKTOR PERPINDAHAN TERHADAP WAKTU YANG BERPENGARUH PADA KINEMETIKA GERAK LURUS BERATURAN (GLB) DAN GERAK LURUS BERUBAH BERATURAN (GLBB)
}

\author{
Sri Prihatini', Wahyuni Handayani ${ }^{1}$ Rena Denya Agustina ${ }^{1}$ \\ ${ }^{1}$ Program Studi Pendidikan Fisika, Fakultas Tarbiyah dan Keguruan, UIN Sunan Gunung \\ Djari Bandung, Indonesia \\ E-mail: sriprihatini.165@gmail.com
}

\begin{abstract}
ABSTRAK
Penelitian ini bertujuan untuk mengidentifikasi faktor perpindahan atau jarak terhadap kinematika gerak lurus. Jenis penelitian ini merupakan penelitian kuantitatif dan kualitatif yang terperinci, terstruktur, jelas dan teranalisis. Penelitian yang dilakukan dengan praktikum menggunakan alat kereta dinamika dan kereta dinamika motor serta alat pendukung lainnya. Dalam penelitian ini, ada beberapa ketentuan jarak atau perpindahan yang akan digunakan, untuk menganalisis secara langsung bagaimana perubahan faktor yang lainnya terhadap kinematika gerak lurus ketika faktor perpindahan berubah-ubah. Dalam penelitian ini juga, menganalisis serta mengidentifikasi perubahan grafik hubungan terhadap waktu pada GLB dan GLBB.
\end{abstract}

Kata kunci: Perpindahan, gerak lurus beraturan, gerak lurus berubah beraturan

\section{ABSTRACT}

This research aims to identify the displacement factor or distance to the straight motion kinematics. This type of research is a detailed quantitative and qualitative research, structured, clear and analytic. Research conducted with practicum using dynamic train tools and motor dynamics trains and other supporting equipment. In this study, there are several conditions of distance or displacement to be used, to analyze directly how other factors change to the straight motion kinematics when the displacement factor changes. In this research also, analyzing and identifying the graph changes in relation to time on GLB and GLBB.

Keywords: movement, uniform linear motion, acceleration linear motion

DOI: http://dx.doi.org/10.15575/jtlp.v2i2.65680

Received: 1 Juli 2017 ; Accepted: 25 Agustus 2017 ; Published: 1 September 2017 


\section{PENDAHULUAN}

Fisika merupakan salah satu cabang Ilmu Pengetahuan Alam (IPA) yang berhubungan dengan proses, sikap, dan produk ilmiah. Ilmu fisika dibutuhkan untuk mempelajari fenomena alam yang menuntut kemampuan berpikir logis dan bertindak nyata secara sistematis, terpadu, dan komprehensif. Siswa dan mahasiswa diharapkan tidak hanya mempelajari tentang konsep, teori, dan fakta ilmiah, tetapi juga aplikasi ilmu fisika dalam kehidupan sehari-hari (Setyorini dkk, 2011).

Percobaan fisika di laboratorium menuntut siswa dan mahasiswa untuk dapat memahami konsep fisika mulai dari yang sederhana sampai dengan yang kompleks. Namun terbatasnya peralatan di laboratorium seringkali menjadi kendala, sehingga demonstrasi contoh nyata pokok bahasan tertentu dalam proses belajar mengajar fisika di sekolah dan di universitas kurang maksimal dan kurang dipahami tentang konsep yang sebenarnya dalam kehidupan sehari-hari. Pembelajaran fisika menjadi tidak kontekstual dan penuh dengan rumus matematis dan abstraksi. Masalah tersebut memberikan dampak negatif terhadap minat dan antusiasme belajar fisika baik siswa maupun mahasiswa. Hal ini akan mengakibatkan pola dan tingkat berpikir yang rendah dan berujung pada pencapaian indikator keberhasilan di bawah standar yang diharapkan.

Dengan menerapkan pembelajaran berbasis praktikum dengan alat dan bahan yang mendukung berlangsungnya praktikum pada pokok pembahasan Gerak Lurus Beraturan (GLB) dan Gerak Lurus Berubah Beraturan (GLBB), maka akan meningkatkan kemampuan berpikir kritis secara objektif dan rasinal pada siswa dan mahasiswa, sehingga mereka memahami secara kontekstual tentang konsep Gerak Lurus Beraturan (GLB) dan Gerak Lurus Berubah Beraturan (GLBB). Konsep tersebut merupakan pendekatan pembelajaran yang memperkenalkan masalah nyata sebagai sarana melatih berpikir kritis dan melatih keterampilan untuk memecahkan masalah yang dihadapi.
Hal ini sesuai dengan tujuan pembelajaran yang menuntut siswa dan mahasiswa mengembangkan kemampuan bernalar dan berpikir kritis dengan menitik beratkan pada aspek logika dalam menerapkan konsep fisika untuk menjelaskan berbagai fenomena alam ( Sutrisno, 2009).

Penelitian melakukan kajian teori fisika pada pokok bahasan Gerak Lurus Beraturan (GLB) dan Gerak Lurus Berubah Berturan (GLBB) terutama dengan mengidentifikan faktor perpindahan terhadap waktu dengan fenomena fisis di laboratorium.

Sebelum memasuki laboratorium, siswa maupun mahasiswa telah meiliki konsepsi sendiri-sendiri tentang kajian Gerak Lurus Beraturan (GLB) dan Gerak Lurus Berubah Beraturan (GLBB) yang akan ditilitinya. Sebelum mereka mengikuti pelajaran kinematika gerak lurus sudah banyak memiliki pengalaman dan peristiwa-peristiwa penting tentang gerak. Karena pengalamannya itu telah memiliki konsepsi-konsepsi yang belum tentu sama dengan konsepsi fisikawan. Konsepsi seperti itu disebut dengan prakonsepsi.

Nilai-nilai perpindahan yang ditentukan menjadi faktor penentu laju kereta dinamika, konsepsi tentang perpindahan yang bernilai dekat dan jauh akan berpengaruh pada waktu laju kereta dinamika tersebut. Untuk itu, dilakukan kajian fisika tentang pokok bahasan faktor perpindahan yang berpengaruh terhadap waktu pada Gerak Lurus Beraturan (GLB) dan Gerak Lurus Berubah Beraturan (GLBB). Kereta dinamika yang dipasang pada rel dengan jarak yang ditentukan, akan digerakkan atau melaju dari titik awal sampai titik yang ditentukan, mengukur waktu menggunakan stopwatch analog dengan Nilai Satuan Terkecil 0,2 second. Dari nilai perpindahan yang telah ditentukan dengan melakukan percobaan yang dibutuhkan, maka akan tercatat nilai waktu-waktu tersebut. Hal ini akan menunjukan grafik hubungan antara perpindahan terhadap waktu pada Gerak Lurus Beraturan (GLB) dan Gerak Lurus Berubah Beraturan (GLBB). Pada Gerak Lurus Berubah Beraturan (GLBB), rel kereta dinamika yang disanggakan pada batang statif akan diletakkan 
dengan sudut tertentu terhadap bidang horizontal.

Melalui penelitian ini, diharapkan siswa maupun mahasiswa terbuka paradigma dan wawasan tentang konsep Gerak Lurus Beraturan (GLB) dan Gerak Lurus Berubah Beraturan (GLBB) yang bermakna sesuai dengan teori belajar Ausubel dan teori Konstruktivisme Piaget.

\section{LANDASAN TEORI}

Suatu pemahaman tentang sebuah benda yang bergerak sekitar abad ke-16 dan ke-17 M oleh beberapa ilmuwan diantaranya Galileo Galilae (1564-1642) dan sir Isaac Newton (1642-1727). Studi terhadap benda bergerak termasuk ke dalam bidang kinematika. (Humaira,Rani,dkk., 2016:66).

Gerak hanya berada di sepanjang garis lurus. Garisnya mungkin vertikal (seperti gerak pada buah yang jatuh dari pohonnya), horizontal (seperti gerak mobil di jalan raya, atau miring, tetapi harus garis lurus. Objek bergerak dapat berupa partikel (yang kita artikan sebuah objek seperti titik, misalnya elektron), atau objek yang bergerak seperti partikel (dimana setiap bagian bergerak dalam arah dan kecepatan yang sama). Seekor babi beku yang tergelincir di atas papan seluncur dapat dipertimbangkan bergerak seperti sebuah partikel: akan tetapi, tumbleweed yang jatuh terguling tidak akan dianggap seperti itu, karena beberapa titik di dalamnya bergerak ke arah yang berbeda. (Halliday.1978:15).

Kita akan mulai dengan benda-benda yang posisinya dapat digambarkan dengan menentukan posisi satu titik agar pembahasan tentang gerak dapat dipahami secara mudah. Benda semacam itu dinamakan partikel. Sebagai contoh, kita anggap bumi sebagai partikel yang bergerak mengelilingi matahari dalam lintasan yang menyeruapi lingkaran. Dalam kasus itu, kita hanya fokus terhadap gerakan pusat bumi, sehingga ukuran bumi dan rotasinya dapat diabaikan. Dalam bidang astronomi, keseluruhan tata surya atau bahkan seluruh galaksi terkadang diperlakukan sebagai partikel. Jika kita menganalisis rotasi atau struktur internal sebuah benda maka kita tidak dapat lagi memperlakukannya sebagai sebuah partikel tunggal. (Frederick. J.2005: 3).

A. Posisi dan perpindahan

Melokasikan suatu objek berarti mencari tahu posisinya relatig terhadap suatu titik rujukan, biasanya titik asal (origin atau titik nol) dari suatu sumbu, seperti sumbu $x$ pada Gambar 1. Arah positif dari sumbu tersebut adalah arah peningkatan jumlah (koordinat), yaitu kearah kanan. Arah sebaliknya merupakan arah negatif.
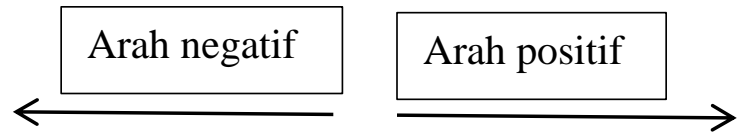

Gambar 1. Arah vektor perpindahan Perubahan posisi dari $x_{1}$ ke posisi lain $x_{2}$ disebut perpindahan $\Delta x$.

$$
\Delta x=x_{2}-x_{1}
$$

Posisi adalah kedudukan benda dari acuan tertentu. Perpindahan (displacement) adalah perubahan posisi dalam selang waktu tertentu. Perpindahan merupakan besaran verktor. Jika hendak berpindah dari posisi awal $x_{1}$ menuju posisi akhir $x_{2}$ maka perpindahannya adalah:

$$
\Delta x=x_{2}-x_{1}
$$

Perpindahan tidak bergantung pada lintasan yang ditempuh benda. Perpindahan hanya bergantung pada posisi awal $\left(x_{1}\right)$ dan posisi akhir benda $\left(x_{2}\right)$.

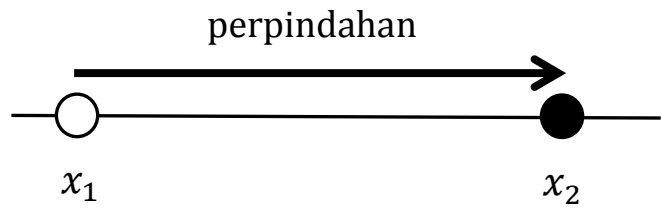

Gambar 2. Skema Perpindahan

Jarak adalah panjang lintasan yang ditempuh oleh benda dalam selang waktu tertentu. Jarak merupakan besaran skalar. (Nuryanti, Ade Yeti dan Septia Mahen, Ea Cahya. 2017 :30-31).

B. Kecepatan dan Kelajuan

1. Kecepatan rata-rata

Jika partikel mengalami perpindahan sejauh $\Delta x$ dan memerlukan waktu $\Delta t$ untuk perpindahan tersebut, maka kecepatan rata-ratanya adalah perbandingan antara perpindahan dengan selang waktu dari perpindahan tersebut. 


$$
v_{\text {rata-rata }}=\frac{\Delta x}{\Delta t}=\frac{x_{2}-x_{1}}{t_{2}-t_{1}}
$$

Kecepatan rata-rata tidak tergantung pada lintasa partikel tetapi tergantung pada posisi awal $\left(x_{1}\right)$ dan posisi akhir $\left(x_{2}\right)$.

2. Kecepatan sesaat

Kecepatan sesaat adalah kecepatan pada saat tertentu atau kecepatan rata-rata yang selang waktunya mendekati nol.

$$
v=\lim _{\Delta t \rightarrow 0} \frac{\Delta x}{\Delta t}=\frac{d x}{d t}
$$

Arah kecepatan sesaat adalah sepancang garis yang menyinggung kurva lintasan benda.

C. Percepatan

1. Percepatan rata-rata

Percepatan rata-rata adalah perubahan kecepatan tiap selang waktu tertentu.

$$
a=\frac{\Delta v}{\Delta t}
$$

$a=$ percepatan rata-rata $\left(\mathrm{m} / \mathrm{s}^{2}\right)$

$\Delta v=$ perubahan kecepatan benda $(\mathrm{m} / \mathrm{s})$

$\Delta t=$ selang waktu yang diperlukan benda untuk bergerak (s)

2. Percepatan sesaat

Percepatan sesaat adalah percepatan rata-rata dengan selang waktu menuju nol. Besarnya percepatan sesaat adalah:

$$
a=\lim _{\Delta t \rightarrow 0} \frac{\Delta v}{\Delta t}=\frac{d v}{d t}
$$

D. Gerak Lurus Beraturan

Gerak lurus beraturan merupakan gerak partikel dengan lintasan berbentuk garis lurus dalam arah yang tetap yang menempuh jarak yang sama dalam tiap satuan waktu. Gerak lurus beraturan biasa dikenal dengan nama Gerak Satu Dimensi dengan Percepatan Nol. Persamaan posisi untuk gerak lurus beraturan adalah:

$$
x=x_{0}+v t
$$

Berikut adalah kurva posisi terhadap waktu untuk GLB

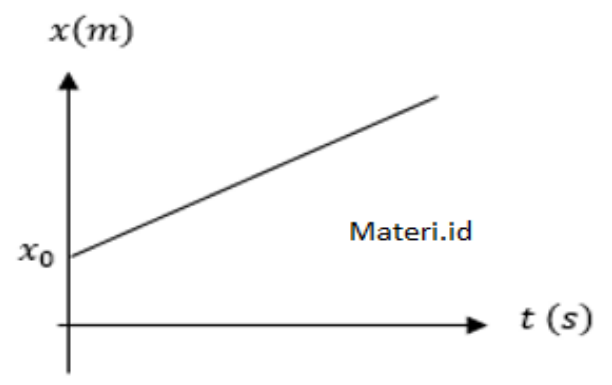

Gambar 3. Grafik jarak terhadap waktu pada GLB Kecepatan benda dalam GLB adalah konstan, sehingga kurva kecepatan trhadap waktunya dapat digambarkan sebagai berikut:

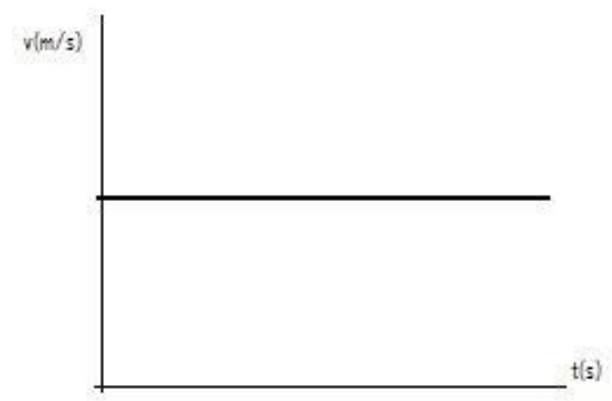

Gambar 5. Grafik hubungan kecepatan terhadap waktu pada GLB

E. Gerak lurus berubah beraturan

Gerak Lurus Berubag Beraturan (GLBB) adalah gerak partikel pada lintasan berbentuk garis lurus dengan arah gerak tetap yang menempuh jarak berubah secara beraturan tiap satu satuan waktu. Gerak Lurus Berubah Beraturan biasa dikenal juga dengan nama Gerak Satu Dimensi dengan Percepatan Tetap).

$$
\begin{gathered}
v_{t}=v_{0}+a t \\
S_{t}=S_{0}+v_{0} t+\frac{1}{2} a t^{2} \\
v_{t}^{2}=v_{0}^{2}+2 a s
\end{gathered}
$$

Berikut adalah kurva perpindahan, kecepatan dan percepatan pada GLBB: 


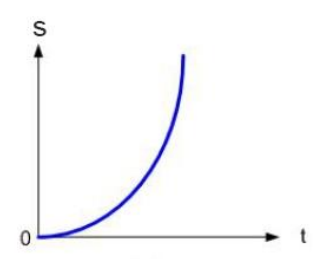

(a)

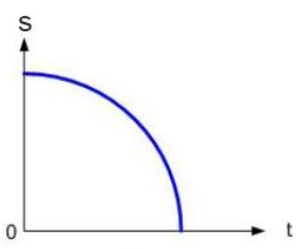

(b)

Gambar 6. Grafik jarak terhadap

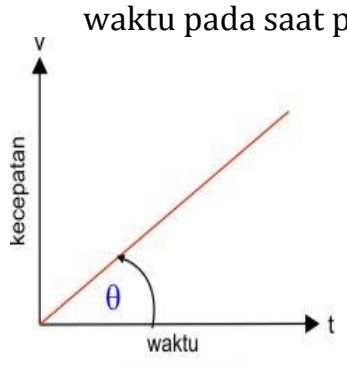

grafik $A$

Gambar 7. Grafik kecepatan terhadap waktu pada saat percepatan konstan

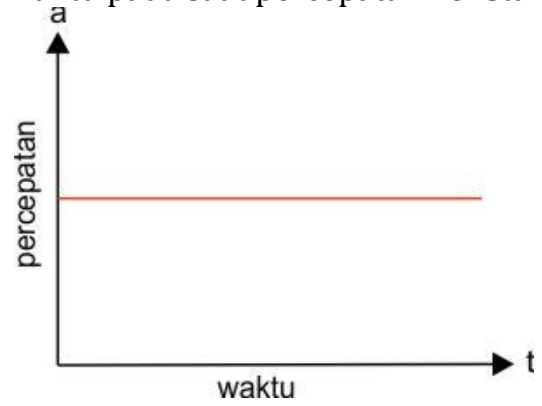

Gambar 8. Grafik percepatan terhadap waktu

\section{METODE PENELITIAN}

Metode yang digunakan dalam penelitian ini adalah eksperimen dengan melibatkan praktikum di laboratorium. Eksperimen tentang Gerak Berubah Beraturan (GLB) dan Gerak Lurus Berubah Beraturan (GLBB) ini melibatkan alat pendukung seperti kereta dinamika motor, kereta dinamika, penggaris busur, stopswatch, batang statis, rel, meteran, penggaris dan kamera yang diperlukan sesuai prosedur percobaan.

Prosedur percobaan dalam praktikum ini yaitu sebagai berikut:

A. Gerak Lurus Beraturan (GLB)

1. Memastikan alat-alat yang akan digunakan dalam keadaan baik.
2. Menyiapkan alat dan bahan serta merakit sesuai gambar 9

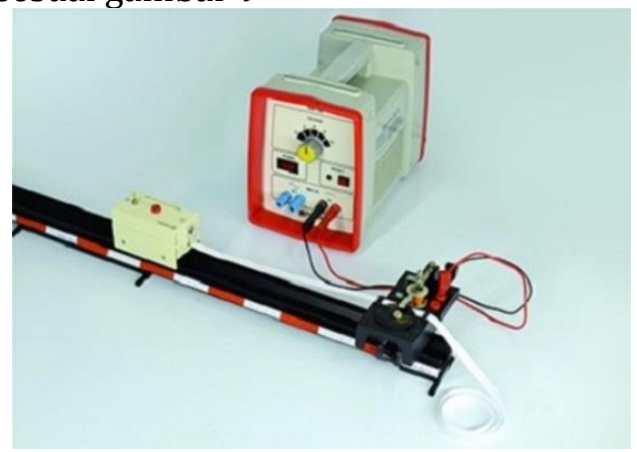

Gambar 9. Rangkaian ticker time

3. Meletakkan kereta dinamika motor pada bidang datar seperti pada gambar 7 .

4. Menentukan panjang lintasan yang akan dilalui oleh kereta dinamika motor.

5. Menyalakan switch kereta dinamika motor pada tombol on.

6. Menekan tombol on pada stopwatch beriringan dengan laju pertama kali kereta dinamika motor bergerak.

7. Menekan tombol stop pada stopwatch ketika kereta dinamika motor berhenti pada akhir lintasannya.

8. Mencatat hasil waktu tempuh pergerakan kereta dinamika motor.

9. Melakukan percobaan tersebut secara berulang sebanyak tiga kali dengan jarak yang berbeda untuk mendapatkan beberapa data yang akan dianalisis.

B. Gerak Lurus Berubah Beraturan (GLBB)

1. Memastikan alat-alat yang akan digunakan dalam keadaan baik.

2. Menyiapkan alat dan bahan serta merakit sesuai gambar 10 .

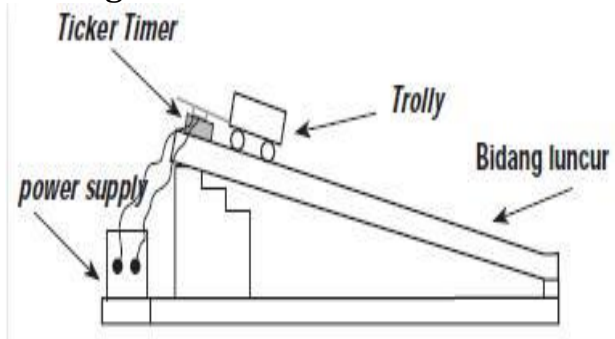

Gambar 10. Rangkaian percobaan 
3. Menentukan sudut kemiringan rel kereta dinamika yang disanggakan pada batang statif terhadap bidang horizontal.

4. Meletakkan kereta dinamika pada puncak atau titik awal rel seperti pada gambar 8 .

5. Menentukan panjang lintasan yang akan dilalui oleh kereta dinamika motor.

6. Menyalakan switch kereta dinamika motor pada tombol on.

7. Menekan tombol on pada stopwatch beriringan dengan laju pertama kali kereta dinamika motor bergerak.

8. Menekan tombol stop pada stopwatch ketika kereta dinamika motor berhenti pada akhir lintasannya.

9. Mencatat hasil waktu tempuh pergerakan kereta dinamika motor.

10.

elakukan percobaan tersebut secara berulang sebanyak tiga kali dengan jarak yang berbeda untuk mendapatkan beberapa data yang akan dianalisis.

\section{HASIL DAN PEMBAHASAN}

Dari percobaan yang telah dilakukan, diperoleh data sebagai berikut:

Tabel 1. Data Hasil Percobaan

\begin{tabular}{ccccccc}
\hline $\begin{array}{c}\text { Perco- } \\
\text { baan }\end{array}$ & $\begin{array}{c}\text { Pengu- } \\
\text { kuran }\end{array}$ & $\begin{array}{c}\text { GLB } \\
(\mathrm{m})\end{array}$ & $\begin{array}{c}\mathrm{t} \\
(\mathrm{s})\end{array}$ & $\begin{array}{c}\mathrm{s} \\
(\mathrm{m})\end{array}$ & $\begin{array}{c}\mathrm{t} \\
(\mathrm{s})\end{array}$ & $\theta\left(^{\circ}\right)$ \\
\hline \multirow{3}{*}{1} & 1 & 0,5 & 3,2 & 1,0 & 1,0 & 15 \\
& 2 & 0,5 & 3,2 & 1,0 & 0,8 & 15 \\
& 3 & 0,5 & 3,2 & 1,0 & 1,0 & 15 \\
2 & 1 & 1,0 & 6,4 & 1,0 & 1,0 & 30 \\
& 2 & 1,0 & 6,4 & 1,0 & 1,0 & 30 \\
& 3 & 1,0 & 6,4 & 1,0 & 1,0 & 30 \\
3 & 1 & 1,5 & 9,6 & 1,0 & 0,8 & 45 \\
& 2 & 1,5 & 9,4 & 1,0 & 0,8 & 45 \\
& 3 & 1,5 & 9,2 & 1,0 & 0,8 & 45 \\
\hline
\end{tabular}

Keseluruhan hasil pengolahan data yang telah dilakukan dalam praktikum menghasilkan beberapa data kuantitatif berupa angka. Berdasarkan hasil yang diperoleh akan dianalisiskan dalam bentuk tabel dan grafik, sehingga akan terlihat jelas bagaimana pengaruh faktor-faktor yang mempengaruhi Gerak Lurus Beraturan (GLB) dan Gerak Lurus Berubah Beraturan (GLBB) serta akan terlihat secara signifikan grafik hubungan posisi atau perpindahan terhadap waktu pada Gerak Lurus Beraturan dan Gerak Lurus Berubah Beraturan (GLBB). Karena dalam praktikum ini melibatkan kamera sebagai alat pendukung untuk mengolah data dalam bentuk tracker.

Berikut ini adalah tabel dan grafik hubungan posisi terhadap waktu:

1. Gerak Lurus Beraturan (GLB)

Tabel 2. Data hasil percobaan GLB

\begin{tabular}{ccc}
\hline PercobaaA & Jarak (m) & Waktu (s) \\
\hline 1 & 0,5 & 3,2 \\
2 & 1,0 & 6,4 \\
3 & 1,5 & 9,6 \\
\hline
\end{tabular}

Berikut ini adalah grafik hubungan posisi terhadap waktu pada aplikasi sofware tracker yang direkam ketika percobaan berlangsung

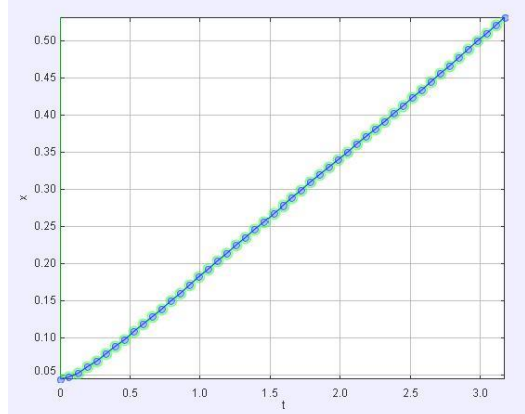

Gambar 11. Grafik GLB jarak 0,5 meter

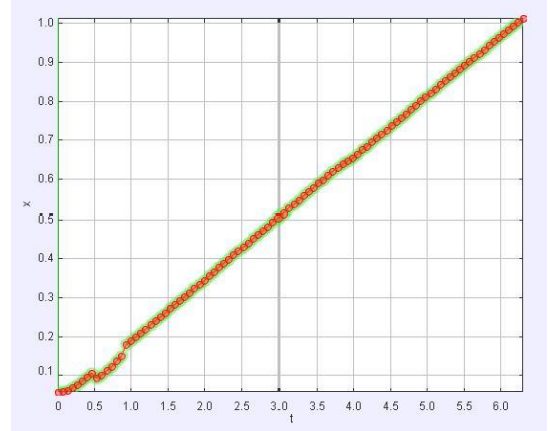

Gambar 12. Grafik GLB jarak 1,0 meter 


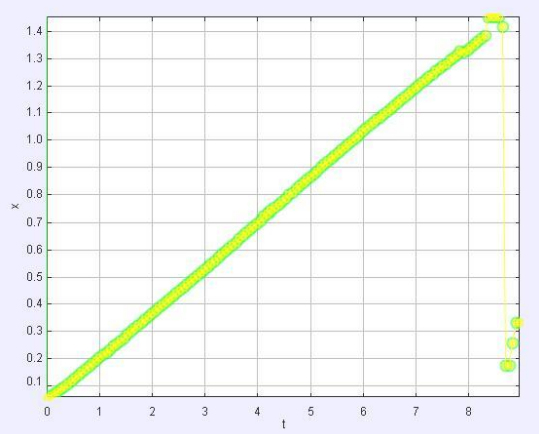

Gambar 13. Grafik GLB jarak 1,5 meter

Dari tabel, grafik dan tracker di atas dapat kita lihat secara jelas bahwa data tersebut menunjukan posisi atau perpindahan yang semakin jauh, maka waktu yang diperlukan kereta dinamika motor tersebut untuk mencapai lintasab yang telah ditentukanpun semakin lama. Hal ini menunjukkan bahwa perpindahan dan waktu mempunyai nilai berbanding lurus. Ketika nilai perpindahan diperbesar, maka nilai waktupun semakin besar (lama), begitu juga sebaliknya.

2. Gerak Lurus Berubah Beraturan (GLBB)

Tabel 3. Data hasil percobaan GLBB

\begin{tabular}{ccc}
\hline Percobaan & Jarak (m) & Waktu (s) \\
\hline 1 & 0,5 & 0,8 \\
2 & 1,0 & 0,9 \\
3 & 1,5 & 1,0 \\
\hline
\end{tabular}

Berikut ini adalah grafik hubungan posisi terhadap waktu pada aplikasi sofware tracker yang direkam ketika percobaan berlangsung

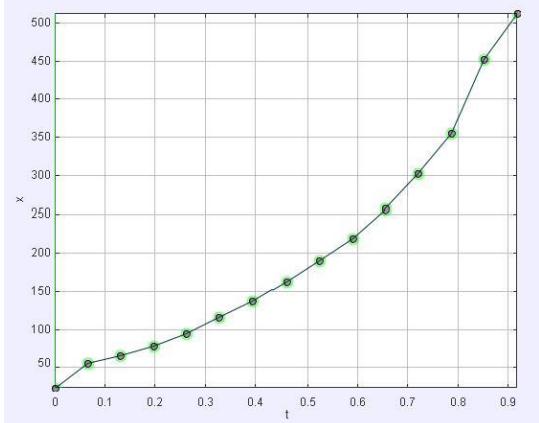

Gambar 14. Grafik GLBB sudut $15^{\circ}$

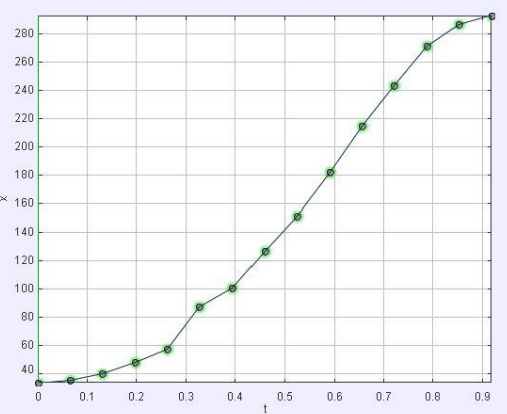

Gambar 15. Grafik GLBB sudut $30^{\circ}$

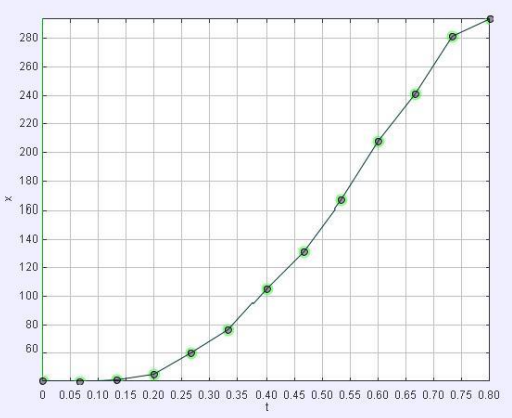

Gambar 16. Grafik GLBB sudut $45^{\circ}$

Dari tabel, grafik dan tracker di atas dapat kita lihat secara jelas bahwa data tersebut menunjukan gerak suatu benda pada lintasan yang lurus dengan percepatan yang bertambah secara beraturan atau dapat dikatakan kereta dinamika ini mengalami perceptan yang konstan, grafik diatas menunjukan gerak dinamika kereta yang mengalami percepatan karena kurvanya terbuka ke atas.

Dalam hal ini menunjukkan bahwa Gerak Lurus Berubah Beraturan (GLBB) menentukan nilai percepatan benda, dengan nilai bercepatan yang konstan dan nilai kecepatan yang berubah-ubah terhadap waktu.

\section{PENUTUP}

Gerak Lurus Beraturan merupakan gerak partikel dengan lintasan berbentuk garis lurus dalam arah yang tetap yang menempuh jarak yang sama dalam tiap satuan waktu. Gerak lurus beraturan biasa dikenal dengan nama Gerak Satu Dimensi dengan Percepatan Nol. Hubungan perpindahan 
ini mempunyai nilai yang berbanding lurus terhadap waktu. GLB ini mempunyai kecepatan yang konstan.

Gerak Lurus Berubag Beraturan (GLBB) adalah gerak partikel pada lintasan berbentuk garis lurus dengan arah gerak tetap yang menempuh jarak berubah secara beraturan tiap satu satuan waktu. Gerak Lurus Berubah Beraturan biasa dikenal juga dengan nama Gerak Satu Dimensi dengan Percepatan Tetap). Gerak Lurus Berubah Beraturan (GLBB) adalah gerak yang lintasannya berupa garis lurus dengan kecepatannya yang berubah-ubah secara teratur dan memiliki percepatan yang konstan. GLBB ini akan mengalami percepatan jika kurva terbalik ke atas, dan GLBB akan mengalami perlambatan jika kurva terbalik ke bawah.

\section{DAFTAR PUSTAKA}

(A.Y \& Dkk, 2017; Abdul \& Dkk, 2015; J, 2005; M.Abdullah, 2007; Medya \& Dkk, n.d.; Pujianto \& Dkk, n.d.; Rani \& Dkk, 2016; Resnick, 1978; S, 2013; Susilawati \& Wijayanto, 2015; Wardani \& dkk, 2013)

A.Y, N., \& Dkk. (2017). Catatan Kuliah Fisika Dasar 1. Bandung: UIN Sunan Gunung Djati Bandung.

Abdul, G., \& Dkk. (2015). Pengembangan e-book Berbasis Flash Kysoft Flip Book pada Materi Kinematika Gerak Lurus sebagai Sarana Belajar Siswa Kelas X. Surabaya.

J, F. (2005). Fisika Universitas Jilid ke-10. Jakarta: Erlangga.

M.Abdullah. (2007). Diktat Fisika Dasar 1. Bandung: Penerbit ITB.

Medya, S., \& Dkk. (n.d.). Analisis Keterampilan Siswa dalam Melaksanakan Praktikum pada Materi Gerak Lurus di SMA. Riau.

Pujianto, A., \& Dkk. (n.d.). Analisis Konsepsi Siswa pada Konsep Kinematika Gerak Lurus. Palu: Universitas Tadulako.
Rani, H., \& Dkk. (2016). Pillar of Physics. Padang: UNP.

Resnick, H. (1978). Fisika Dasar. Jakarta: Erlangga.

S, N. (2013). Metode Penelitian Pendidikan Bandung. Bandung: PT. Remaja Rosdakarya. Susilawati, \& Wijayanto. (2015). Rancangan Kinematika Gerak Lurus. Semarang: Universitas PGRI Semarang.

Wardani, \& dkk. (2013). Tinjauan Ulang Materi Ajar Gerak Lurus Beraturan melalui Percobaan Gravty Cirrent dalam Skala Laboratorium. Surabaya: Universitas Negeri Surabaya. 